\title{
The ELECTIONS IN THE CiTIES: YET ANOTHER DEFEAT FOR THE CENTER-RIGHT
}

\author{
Guido Legnante
}

In 2004, for the third successive year, the center-left opposition achieved political success in the local elections, while the center-right government suffered a clear defeat. The headlines of the main daily papers were unequivocal: "Cities and Provinces, the Victory of the CenterLeft" (Corriere della Sera, 15 June); "Olive-Tree Coalition Victorious in the Cities" (la Repubblica, 15 June); "The Center-Left Wins the Race in Milan" (Corriere della Sera, 28 June); "The Polo Loses Even in Milan" (la Repubblica, 28 June); "The Center-Right Hands Milan over to the DS" (Il Giornale, 28 June). The 2002 and 2003 elections had already registered clear victories for the center-left, not least because of the symbolic importance of the successes of Riccardo Illy in Friuli-Venezia Giulia and Enrico Gasbarra in the Rome provincial elections.

Yet there were reasons to emphasize just how localized the factors were that had led to these results, how little significance the actions of either government or opposition had had in bringing them about, and thus what little solid ground they offered for forecasting future results. The center-left's success could indeed be traced back, in large measure, to local circumstances, while the defeat of the center-right was probably connected both with the tensions existing among the parties in government and with the excessive emphasis placed on the national leader, who had entirely overshadowed the autonomy and image of

Notes for this chapter begin on page 81 . 
local candidates. ${ }^{1}$ In many respects, as we shall explain shortly, the 2004 results, though even more decisive than those of 2002 and 2003, reveal similar traits and urge the same degree of caution.

Yet in politics, perceptions count. Indeed, the third consecutive defeat for the House of Freedoms is more serious than the earlier ones, on the one hand, because it was made all the more decisive by the result in Bologna (which in 1999 had symbolized the centerright's drive toward the 2001 general-election victory and which has now returned to the center-left, being the first major city to see an outgoing mayor defeated in a two-horse race), ${ }^{2}$ and, on the other, precisely because it is the third loss in a row, thus encouraging the notion that there is something systematic underlying the defeats of the center-right.

The 2004 local elections involved more than 4,000 town councils and rather fewer than 19 million voters. Of these latter, very nearly 8 million were concentrated in 231 centers of more than 15,000 inhabitants, ${ }^{3}$ among which were 30 regional or provincial capitals. ${ }^{4}$ The first part of this chapter advances a number of ideas about how these election results should be seen in the context of the Italian electoral cycle, and just how representative the centers that voted are in national terms. The second and third parts offer some structured thoughts about the actual election results, while the fourth is concerned with an analysis of the vote in Bologna and in the other major cities. The fifth and sixth sections discuss the outcomes of this round of elections and the prospects they offer for the next round.

\section{The Role of the Local Elections in the National Electoral Cycle}

In 2004, the local vote and the European elections, held at the same time, ushered in a national "cycle" that will see elections in the 15 ordinary-statute regions in 2005 and a general election in 2006. In recent years, Italian electoral history has revealed certain traits suggesting the existence of cycles that precede general elections and, in some way or other, influence-or at any rate presage-the outcomes of such elections. In 1995, the center-left won the regional elections, and in 1996, the general election. In 1999, the center-right won Bologna, the symbolic city of the center-left, and in 2000 also the regional elections, which led to the resignation of Massimo D'Alema, president of the Council of Ministers; in 2001, it went on to win the general election.

For experts, the hypothetical existence of these cycles makes analysis of the national significance of "partial" elections even more significant, 
and for political actors and the media, it makes the temptation to attach the labels "winner" and "loser" to the contestants even more irresistible. The political actors, besides seeking clues about forthcoming rounds of elections, try to cash in at coalition negotiating tables any gains they may have made, and to construct for themselves a "victorious" image that will serve to mobilize their voters at the next elections. ${ }^{5}$ The media seek to present news about the elections in such a way as to make them significant for the general public. This means, on the one hand, often stressing their "novel" character (suggesting that such novelty resides in the behavior and motivation of "floating" voters) and, on the other, offering a variety of interpretations (first among which being the "verdict" of the voters on the government in power) that are of interest to those who keep abreast of the news and are applicable even to areas where there has been no vote.

Of an often rather different character are the notes of caution sounded by experts with regard to the local or national significance of the results, the extent of the voting shifts, their interpretation, and the significance of the results for the purposes of predicting the outcomes of future elections. To the question "Who won the local elections?" one could, in fact, respond in a number of different ways ${ }^{6}$ by referring to those who won the largest number of seats; those who won the seats considered as being of the most symbolic, economic, demographic, or political importance; those who won in places previously governed by their opponents; those who increased the size of their electoral support; or those who appear likely to win future, more broadly based elections. It is already clear from this incomplete list that a meticulous reply to this question demands a degree of conceptual clarity and of precision in the choice of methodology that is almost impossible to achieve in time for on-the-spot broadcasts of election results. But it is the same question- "Who won?"- that would probably need to be discussed if the local elections were observed from a national perspective. This is especially so after the reform introducing the direct election of mayors, since the institutional autonomy of local elections has, in fact, been greatly enhanced. ${ }^{7}$ Direct election has personalized the selection of candidates as well as the election campaigns, with the result that alongside questions of policy and the logic of alignments, personal qualities have frequently been highlighted in local political campaigns, while the variability of choices of coalition partners made by the parties has further emphasized local issues. The voters, for their part, have demonstrated a high level of sensitivity toward the stimuli of political choice, which has often compelled them to abandon the logic of alignments and to cast their votes in a personal manner, allowing them to be more heavily influenced by local issues. Faced with 
these considerations, the fact that the political alternatives on offer are, despite their variation, comparable from one election to the next, and that many voters' choices are more influenced by medium- or long-term loyalties than by local issues, justifies the search for a comprehensive understanding of the results, but it does not eliminate the need for caution in undertaking this task.

Finally, a further note of caution must be sounded with regard to the national significance of the outcomes of local elections when they take place in geographical areas that are substantially different in character from that of a general election. In the 2004 elections, for example, the "red belt" was decidedly over-represented, with 13 provincial capitals and a further 77 larger urban centers voting-as against 7 provincial capitals and another 71 larger urban centers in the north, and 10 provincial capitals and 53 larger urban centers in the central and southern regions. ${ }^{8}$ As is shown in table 2.1, in the 2004 elections, the "red belt," which in general elections returns somewhat fewer than one-sixth of the deputies elected in constituencies, accounted for slightly less than half of the provincial capitals and more than a third of the other larger urban centers where voting took place.

TABLE 2.1 The unrepresentative character of the provincial capitals and other larger urban centers where voting took place in 2004

\begin{tabular}{lccccc}
\hline & North & "Red Belt" & Center-South & Total & N \\
\hline $\begin{array}{l}\text { Provincial capitals } \\
(2004 \text { elections) }\end{array}$ & $23.3 \%$ & $43.3 \%$ & $33.3 \%$ & $100.0 \%$ & 30 \\
\hline $\begin{array}{l}\text { Other large urban } \\
\text { centers (2004 elections) }\end{array}$ & $35.3 \%$ & $38.3 \%$ & $26.4 \%$ & $100.0 \%$ & 201 \\
\hline $\begin{array}{l}\text { Chamber of Deputies } \\
\text { constituencies }\end{array}$ & $37.9 \%$ & $16.8 \%$ & $45.3 \%$ & $100.0 \%$ & 475 \\
\hline
\end{tabular}

The unrepresentative nature of geographical areas over-represented in one election or another adds to the likelihood of local elections suggesting cycles in which the electoral strength of one or another of the political coalitions is predominant. With respect to voting in general elections, however, the growing autonomy of the local vote, mentioned above, with voters being less loyal to their own political affiliations and showing greater sensitivity to local election promises, makes the occurrence of deviations from the politico-electoral characteristics of given areas (that is, compared with what happens in general and regional elections) relatively more frequent. In other words, a center-left candidate may be elected mayor in areas where the center-right is strong 
(that is, in the north) or a center-right candidate may be elected mayor in areas where the center-left is strong (that is, in the central regions).

\section{The 2004 Election}

The local elections in 2004 took place at the same time as the provincial but also, more importantly, the European elections. ${ }^{9}$ Since both the president of the Council of Ministers, Silvio Berlusconi, and the opposition's chief contender for the leadership, Romano Prodi, were directly or indirectly involved in the latter, issues pertinent to the local elections struggled to capture the attention of the media and observers. For this reason, it was not a foregone conclusion that the 2004 vote would confirm the autonomy of the local elections with respect to the European elections-though that is precisely what did happen.

This autonomy was expressed above all in the political choices on offer, since the main novelty of the European election, the Uniti nell'Ulivo list, was not present in the elections in any of the 30 provincial capitals-something that can certainly not be attributed solely to the fact that the local electoral system encourages the fragmentation of lists for the town council to an even greater extent than does a purely proportional system, like that for the European elections. ${ }^{10}$ The autonomy of the local elections was also expressed in the vote: what observers saw as the main point at issue-namely, whether or not Italians were dissatisfied with the Berlusconi government-was a question to which the European and the local votes provided different answers. In the European elections, a significant proportion of Forza Italia voters (to a greater extent than center-right voters generally) took a "wait-and-see" stance, not voting for their own party but not defecting in any significant numbers to the center-left or the Uniti nell'Ulivo list. In the local elections, on the other hand, the center-left coalition appeared to be significantly healthier than the center-right.

Table 2.2 shows how the results varied depending on whether local councils were previously in the hands of the center-left or the centerright. The center-left was successful in capturing half of the councils previously governed by the center-right-that is, they captured 5 provincial capitals out of 10 (50 percent), and 29 of the 57 other larger councils (50.9 percent). On the other hand, the center-right managed to take far fewer councils that had previously been in the hands of the center-left-that is, they took 3 provincial capitals out of 20 (15 percent), and 17 of the 137 other larger councils (12.4 percent). ${ }^{11}$ However, just as in 2003, while the results were unambiguous in terms of the overall picture they presented (a net increase for the center-left), 
they also had a "bidirectional" character in that while many urban centers were won by the center-left, there were quite a few taken by the center-right-a combination of features that confirms the strength of the local influences on the outcome of the elections.

TABLE 2.2 Councils held or captured by the center-left and the centerright in the elections of $2004(N=224)$

\begin{tabular}{l|lll|ll}
\hline \multicolumn{5}{c}{$\begin{array}{c}\text { Provincial } \\
\text { Capitals }\end{array}$} & $\begin{array}{l}\text { Other } \\
\text { Councils }\end{array}$ \\
\hline $\begin{array}{l}\text { Previously admin. } \\
\text { by the center-left } 157\end{array}$ & $\begin{array}{l}\text { Retained by } \\
\text { the center-left }\end{array}$ & 17 & 120 & $\begin{array}{l}\text { Now administered } \\
\text { by the center-left }\end{array}$ & 171 \\
\cline { 2 - 4 } & $\begin{array}{l}\text { Won by the } \\
\text { center-right }\end{array}$ & 3 & 17 & \\
\hline $\begin{array}{l}\text { Previously admin. } \\
\text { by the center-right } 67\end{array}$ & $\begin{array}{l}\text { Won by the } \\
\text { center-left }\end{array}$ & 5 & 29 & $\begin{array}{l}\text { Now administered } \\
\text { by the center-right }\end{array}$ & 53 \\
\cline { 2 - 4 } & $\begin{array}{l}\text { Retained by } \\
\text { the center-right }\end{array}$ & 5 & 28 & \\
\hline
\end{tabular}

Focusing on the 30 provincial capitals involved in the elections and moving from north to south, the center-right retained Imperia, Arezzo, Ascoli Piceno, Viterbo, and Siracusa in 2004, while the center-left retained Biella, Verbania, Cremona, Ferrara, Forlì, Modena, Reggio Emilia, Florence, Livorno, Prato, Perugia, Terni, Pesaro, Campobasso, Avellino, Potenza, and Caltanissetta. The center-right captured Vercelli, Teramo, and Brindisi, the center-left, Bergamo, Padua, Bologna, Bari, and Foggia. In 2003, the center-left had won in six provincial capitals, the center-right, in four, but most significantly of all, the former had made high-profile conquests in the Friuli-Venezia Giulia region and in the Rome province, while retaining the Trento province with an overwhelming majority. Even earlier, in 2002, although then the picture was more balanced, the center-left's victories in Verona and Monza had set alarm bells ringing for the government coalition.

In short, over and above the influence of local factors, the 2004 council elections pointed to a clear victory for the center-left, especially in the center and the north. In the south, the outcome, though favorable to the center-left, was more balanced, clearly maintaining the trend set by the local election results in previous years. The geographical distribution of the councils involved in the elections-weighted toward areas where the center-left is strong-exposed the center-left itself to the risk of contraction within its own strongholds (in all, it had 157 outgoing administrations as against 67 for the center-right). But in fact the center-left won 171 councils as against 53, a victory 
that is as notable as is the defeat of the center-right. Nevertheless, it is at first sight difficult to draw "national" conclusions from this result. The center-left captured 50 percent of the municipalities previously governed by its opponents, while the center-right captured only 15 percent of those previously in the hands of the center-left. In terms of the absolute figures, however, the gap is smaller: the center-left captured 34 municipalities, the center-right, 20. The latter number, while lower than the corresponding number for the center-left, is still too high to permit assertions about any generalized weakness of the center-right. The relative evenness of the outcome in the south, in particular, confirms that all generalizations about the outcome (and even more so, all future projections) should be treated with extreme caution.

\section{Outgoing Mayors}

Since 1997 (the first year in which they sought re-election), directly elected mayors have always registered very high re-election rates. ${ }^{12}$ In the larger councils voting in 2003,89 percent of outgoing centerleft mayors were re-elected, while only 40 percent of those from the center-right enjoyed the same success. ${ }^{13}$ The 2004 election presents a similar picture. As can be seen in table 2.3, all five outgoing center-left mayors were re-elected, whereas the center-right managed to re-elect only five out of eight. (In addition to losing the first rounds in Bologna and Padua, they also lost the second ballot in Bergamo.)

TABLE 2.3 Election results for outgoing mayors in provincial capitals

\begin{tabular}{lccc|ccc|c|c}
\hline & \multicolumn{3}{c}{ Victorious } & \multicolumn{3}{c}{ Defeated } & $\begin{array}{c}\text { Re-election Rate } \\
\text { for Mayors }\end{array}$ \\
\hline & $\begin{array}{c}\text { 1st } \\
\text { round }\end{array}$ & $\begin{array}{c}\text { 2nd } \\
\text { round }\end{array}$ & Total & $\begin{array}{c}\text { 1st } \\
\text { round }\end{array}$ 2nd & & & \\
\hline Ulivo & 4 & 1 & 5 & - & - & - & 5 & $100.0 \%$ \\
\hline $\begin{array}{l}\text { House of } \\
\text { Freedoms }\end{array}$ & 4 & 1 & 5 & 2 & 1 & 3 & 8 & $62.5 \%$ \\
\hline
\end{tabular}

However, it is interesting to observe (table 2.4) that only where its mayoral candidates were incumbents did the center-right manage to retain control of any provincial capitals; in Bari and in Foggia, the center-right's candidates were defeated, along with the outgoing administrations, by the candidates representing the forces of the center-left opposition. The center-left, on the other hand, managed to retain 
control of 12 out of the 15 councils that it had administered previously and in which the outgoing mayor did not stand for re-election, losing only in Vercelli, Teramo, and Brindisi.

TABLE 2.4 Election results in provincial capitals where the outgoing administration presented a non-incumbent mayoral candidate

\begin{tabular}{lccc|ccc|c|c}
\hline & \multicolumn{3}{c}{ Victorious } & \multicolumn{3}{c}{ Defeated } & \multicolumn{1}{c}{$\begin{array}{c}\text { Re-election Rate } \\
\text { for the Admin. }\end{array}$} \\
\hline & $\begin{array}{c}\text { 1st } \\
\text { round }\end{array}$ & $\begin{array}{c}\text { 2nd } \\
\text { round }\end{array}$ & Total & $\begin{array}{c}\text { 1st } \\
\text { round }\end{array}$ rnd & round & Total & $\mathrm{N}$ & \\
\hline Ulivo & 11 & 1 & 12 & 2 & 1 & 3 & 15 & $80.0 \%$ \\
\hline $\begin{array}{l}\text { House of } \\
\text { Freedoms }\end{array}$ & - & - & - & 1 & 1 & 2 & 2 & $0.0 \%$ \\
\hline
\end{tabular}

To sum up, from the analysis of the overall dynamics of the local elections presented in this and the preceding section, it emerges that in 2004 , as in previous years, the center-left was successful, more or less across the board, in increasing the number of councils it controlled. This was despite the geographical location of the councils involved in the elections, which placed the center-left on the defensive. The center-left achieved its victory both by "retrieving" councils in its own strongholds and by being fully competitive even in other parts of the country. In this respect, outgoing mayors proved to be an important resource for both coalitions, but often the center-left succeeded in retaining control even when it had to replace its mayors (frequently because they had come to the end of their second consecutive term and were therefore not eligible to stand again). The not insignificant number of councils that passed from the center-left to the centerright leads us, however, to doubt that the outcome was the result of national factors.

\section{Bologna and the Other Major Cities}

Notwithstanding the importance of the European elections, the candidatures, projected outcomes, and voting in the main cities attracted a certain level of media attention. For example, in the months leading up to polling day, the main dailies presented "vignettes" on the elections in 20 or so cities that either were provincial capitals or were believed to be particularly significant. The city that commanded more attention among commentators than any other was undoubtedly Bologna, the 
scene, in 1999, of the "unexpected defeat" that had symbolized the crisis in relations between the center-left government (and especially its main party, the Left Democrats [DS]) and its supporters. ${ }^{14}$ The importance of the Bologna elections (and, conversely, the sparse interest in the provincial elections) is shown, for example, by an ISPO (Istituto per gli Studi sulla Pubblica Opinione) poll, which showed that three weeks before the elections, more than 80 percent of the citizens of Bologna were able to name spontaneously the two chief contenders for the post of mayor, while a little less than half of the inhabitants of the province of Milan were capable of doing the same with regard to their candidates in the provincial elections. ${ }^{15}$

In Bologna, the outgoing mayor, Giorgio Guazzaloca, was up for re-election. This was a man who, first during the electoral campaign and then later in the city government, had distinguished himself by stressing the all-around nature of his politics, expressing admiration, willingly and often, for previous Bolognese city councils. The candidature of his challenger from the center-left, Sergio Cofferati, had aroused even greater interest. By the start of the summer of 2003, after an intense period of political activity connected also with the demonstrations against the war in Iraq, this former trade-union leader had already indicated his desire to stand for mayor in Bologna, finding a substantial consensus among the various components of the center-left. While on the one hand, this candidature could be seen as a confirmation of the capital importance of the local, and specifically the urban, level in the new-style political careers, ${ }^{16}$ and therefore as a "spring-board" to more important posts at the national level, on the other hand, one could ask why Cofferati had, as it were, turned back to the local level despite his own central position in public life at the national level. One possible explanation lies in the hypothesis that at the national level Cofferati's electoral strength was, in reality, less than quite a few commentators estimated it to be. An investigation into the policy directions and basic values of the DS suggested, in fact, that the moment he became a candidate, Cofferati-despite his undoubted personal appeal-would have to make some difficult choices when spelling out his own policy proposals. ${ }^{17}$

Furthermore, Cofferati's candidature represented the denial of certain hypotheses advanced in recent years, such as that to be successful a candidate had to be someone other than a politician, especially when challenging an outgoing mayor who had made his reputation largely as a result of his non-political status. The underlying logic of Cofferati's candidature was probably that (in keeping with what analyses of the 1999 elections revealed) ${ }^{18}$ a majority of the Bolognese electorate was still close to the center-left and that it was a matter of 
finding a candidate capable of mobilizing such a vote, rather than focusing on the non-political status of the candidate in an attempt to curry favor even among voters of a different political orientation.

The election results confirmed the rationality of this approach. Guazzaloca was decisively beaten by Cofferati in the first round. Reliance on his personal vote-calling on center-left supporters to vote two ways-for a center-left party for the city council but for Guazzaloca as mayor-proved insufficient for the outgoing mayor. ${ }^{19}$ While it resulted in a large gap between the number of votes cast for the mayoral candidate on the one hand, and those cast for his coalition on the other (for every 100 votes gained by the parties supporting him, he received 122), Guazzaloca remained stuck at 40.9 percent as against Cofferati's 56.3 percent (the latter receiving 113 votes for every 100 votes gained by the parties that supported him). ${ }^{20}$

These figures show that success based on a strong personal reputation does not guarantee an endless/open-ended mandate. If it is possible for mayors to emphasize their non-political qualities through their actions, then they can stand again as "non-political" candidates. But it is by no means certain that this in itself will be sufficient, especially in cities whose political traditions and identities have their own particular character. Playing the non-political card worked well for Illy in the 1993 local elections in Trieste, and then again in 1997 (and yet again in the 2003 regional election), ${ }^{21}$ while for Guazzaloca it worked in 1999 but not in 2004. It is very likely that the novelty and the nonpolitical stance of Guazzaloca's candidature had been diluted by his five years in office when he swung between high-profile innovation, on the one hand, and being careful not to appear too different from previous administrations, on the other. In all probability, Guazzaloca turned out to be rather too "apolitical" in the eyes of center-right voters who had voted for him, while being too closely identified with the center-right in the eyes of center-left voters who had abstained (or had even voted for him) five years previously. The success of the centerleft's strategy of "politicizing" the vote in Bologna shows, in fact, that the personal and/or anti-political vote is an important competitive expedient but not the only one. Like others (ideology, programs, etc.), it can be more useful in some circumstances than in others.

Another city in which council election candidatures were affected by the lively debate between "movimentisti" and parties was Florence, where a civic list closely identified with the "girotondi" was critical of the outgoing DS mayor, Leonardo Domenici, who was accused of deviousness and of having insufficient regard for the precepts of rank-and-file democracy. With Domenici forced into a second, though unproblematic, ballot, the election results confirmed the existence of a 
not insignificant number of voters who were closer to the "girotondi" than to the center-left, but who, for the most part, nevertheless voted for the outgoing mayor at the second ballot.

In addition to the victory in Bologna, the center-left captured Bari, Foggia, Bergamo, and Padua of the provincial capitals, while the center-right took Vercelli, Teramo, and Brindisi. Bari proved to be a place of particular interest with regard to the origins and political stance of the candidates. The center-right candidate, Luigi Lobuono, was successfully opposed by the center-left candidate, Michele Emiliano, a former magistrate who cited, among his models of good government, the example of the ex-mayor of New York, Rudolph Giuliani, and his program of "zero tolerance." An indication of the "repoliticization" of the candidates came, however, from Padua, where the outgoing center-right mayor, Giustina Destro, was defeated by the former mayor of the center-left, Flavio Zanonato.

\section{After 2004}

As table 2.5 shows, the 2004 elections fit into a local government electoral cycle that is clearly favorable to the center-left: over the last three years the latter has won more provincial capitals than it has lost to its rivals (a total of 13 against 6), while during the previous five years, the opposite had occurred. After the success of the left in the early local government elections (particularly in 1993), it had been mainly the center-right that had gradually conquered (for a total of 30 against 9) the provincial capitals whose outgoing administrations had been of the center-left. ${ }^{22}$

There are three possible explanations for this dynamic: alternation at the local level, the role of the government or the opposition at the

TABLE 2.5 Councils held or captured by the center-left and center-right from 1997 to 2004

\begin{tabular}{lcccccccc}
\hline & $\mathbf{1 9 9 7}$ & $\mathbf{1 9 9 8}$ & $\mathbf{1 9 9 9}$ & $\mathbf{2 0 0 0}$ & $\mathbf{2 0 0 1}$ & $\mathbf{2 0 0 2}$ & $\mathbf{2 0 0 3}$ & $\mathbf{2 0 0 4}$ \\
\hline $\begin{array}{l}\text { Held by the } \\
\text { center-left }\end{array}$ & 15 & 9 & 19 & 7 & 10 & 9 & 3 & 17 \\
\hline $\begin{array}{l}\text { Won by the } \\
\text { center-left }\end{array}$ & 3 & 3 & 1 & 1 & 1 & 5 & 3 & 5 \\
\hline $\begin{array}{l}\text { Won by the } \\
\text { center-right }\end{array}$ & 5 & 12 & 7 & 2 & 4 & 2 & 1 & 3 \\
\hline $\begin{array}{l}\text { Held by the } \\
\text { center-right }\end{array}$ & 10 & 8 & 3 & 3 & 9 & 11 & 3 & 5 \\
\hline
\end{tabular}


national level, and greater or lesser specialization in local election campaigning. As far as the first possibility is concerned, the high number of re-elections of outgoing mayors compels us to reject the notion that what occurred can be explained in terms of a simple alternation from one legislature to the next. Alternation, in fact, takes place over longer electoral cycles; in about half of the Italian provincial capitals, there has been at least one change of majority since mayors came to be elected directly. In this regard, one plausible hypothesis-on which, though, we have no systematic empirical data-is that alternation occurs in the election following that in which the outgoing mayor is re-elected.

Let us consider the second possibility. The figures in table 2.5 show that from 1997 to the present, the coalition that was in opposition at the national level has been more successful in taking provincial capitals from its opponent than has the coalition that was in governmentthat is, the center-left up to the 2001 elections, which were held at the same time as the general election, and after that, the center-right. This hypothesis undoubtedly has certain aspects to recommend it. For example, when governing nationally, the temptation can be greater for parties to make their local-level power felt at the coalition negotiating table by seeking to distinguish themselves from their allies. Those in opposition, on the other hand, may have much greater incentive to seek unity in the local elections, either to demonstrate their ability to construct a future alternative government, or because they have less reason to advertise their own internal divisions. In the last three-year period, as a matter of fact, the center-right has often given the impression in local elections of mirroring (at least, up to just prior to the local elections) the latent tensions among the parties in government. When in government, party secretariats, the national factions, and-even more-the local party branches tend to look upon the local elections more as an opportunity for a "division of the spoils" than as a race still to be won (this being especially true in contests where victory is expected, as was the case for the center-right in Friuli-Venezia Giulia in 2003 and for the center-left in Bologna in 1999). On the other hand, the center-left has often found, at least in terms of local candidatures, the very unity that has not always been evident in the words and behavior of its elites in Parliament. It is beyond the scope of this article to reflect on whether or not the excellence of the Ulivo's strategic choices at the local level can be attributed to the far-sightedness of its leaders or, on the contrary, to a lack of national-level leadership that has allowed the local parties more autonomy. What one can say is that while squabbles have persisted at the national level, local parties have demonstrated a real capacity for unifying in support of candidates who have been appreciated by the voters. 
Its flexibility in its choice of candidates in local elections has ensured that in recent years the center-left has come up with a range of alternatives directed at fielding candidates who have a real chance of winning. One of its most successful strategies has been to promote candidates who could be characterized, above all, by their personal qualities and their ability to push the "political" aspects of the elections into the background, asking voters to make a "detour" with respect to their political identities rather than asking them to forsake or abandon those identities. ${ }^{23}$ This model, used successfully by Riccardo Illy in 2003, was replicated, for example, in the regional elections in Sardinia, where the entrepreneur Renato Soru won the first round with a margin of around 10 percent over the center-right candidate, Mauro Pili. The year 2004 has added further examples, such as that of Bologna (or the province of Milan, the other highly symbolic success of 2004), which have favored the return even of candidates with a distinctly "political" profile. In short, the center-left's victorious candidates have been characterized by their variety, coming from the left as well as from the center, from civil society as well as from the ranks of career politicians. The impression gained from the coalition's offering is that, composite though it is, one of the main points of similarity among these candidatures (which in biographical terms are very varied) is the greater ability (as compared to the center-right) to achieve a high degree of local-level unity and inclusiveness. As is often the case with those who are in opposition at the national level, the Ulivo parties have frequently been able to construct local-level coalitions with relatively little conflict, and they have often done so while managing to include both civic lists and parties (such as RC or the Di Pietro-Occhetto tandem) that are otherwise particularly critical and confrontational toward the Ulivo.

These aspects also tie in with the third possibility, namely, that the center-right (at least in the present legislature where it is in government) is less specialized in local campaigning. The notion that success starts from victory in local elections, later bearing fruit at the national level, is not a new one. ${ }^{24}$ Voters in Italian towns seem to like those candidates who concentrate on local issues in local elections, detaching local matters from questions of national politics (as the centerright was among the first to demonstrate in the Bologna elections of 1999). Particularly since it took over the government, the center-right coalition seems to have experienced increasing difficulty adopting this approach. This is partly a result of internal conflict and-to an even greater degree-the result of increasingly single-minded concentration of its political focus on the figure of Berlusconi and on national political issues. In many areas, the center-right's local political agenda 
has, in terms of choices, issues, and practices, appeared to be tied too closely to those of the national leadership. In fact, it is quite possible that the scant appeal to many of the House of Freedoms' local candidates stems not from center-right voters' dissatisfaction with the government-indeed, support for the center-right coalition largely held up in the European elections, even though there was a change in the balance of power among its individual parties-but rather from the fact that voters who appreciate Berlusconi's leadership at the national level will not necessarily appreciate to the same degree local candidates who simply present themselves as smaller versions of the Forza Italia leader. Previously, during the "First Republic," the political forces that were organizationally most deeply entrenched at the local level and/or had no immediate prospects of access to national government did better in local elections than in general elections (contrary to what happened to the "opinion" parties such as the Liberals or the Republicans, which were more concerned with national issues). However, in the "Second Republic," it is probable that this specialization should be taken into consideration in a more systematic way. The most recent electoral contests have, in fact, brought to the fore an analogous but much more marked phenomenon, namely, specialization of the House of Freedoms, and most of all Forza Italia, in national elections to the detriment of returns in local elections (where Forza Italia's coalition partners-the National Alliance (AN), the Union of Christian Democrats and Center Democrats (UDC), and the Northern League-often do well, sometimes at the expense of Forza Italia).

\section{Toward 2005}

The local elections, with their repeated defeats for the center-right, the clear defeat of Forza Italia in the European elections, and popular dissatisfaction with the government, as revealed by opinion polls, have all contributed to a growing expectation, among observers and political actors, of a center-left victory in the next elections. Such expectations and perceptions can cut both ways. At the elite level, they will influence the strategies and choices of the political players. At the mass level, they can influence voting trends either by motivating the potential electors of the two coalitions to campaign and to vote to make sure of their victory or to defeat their opponents, or by demotivating the potential losers while convincing supporters of the potential winners that their votes are not really important. These effects are not substantially different from those that can result from opinion polls, which, on the one hand, can increase a candidate's popularity and, on the other, 
encourage the losing candidate to mount a comeback. The public perception of who is the likely "winner" and who is the "loser" in a given political situation may reflect deeper-lying tendencies than those that can be discerned from an analysis of the vote. It is no accident that among the indicators of the strength of coalitions and parties, there is, besides voting intentions, voters' perceptions of the likelihood of victory for one line-up or the other at the forthcoming elections. ${ }^{25}$

With its successes in the local elections during these past few years, the Ulivo has certainly put behind it the "loser" image it had clearly had in the run-up to the 2001 general election. In particular, its significant success in the north gives the impression that even here, where it had won few seats in the general election, the Ulivo may turn out to be fully competitive. It is possible that a greater emphasis on the local vote in 2004 might have further reinforced the image of a "winning" force, not least because the European vote in fact produced a situation in which there were many losers and no victors (and in which, though the Ulivo incurred fewer losses than Forza Italia, the single list's fortunes were mixed).

However, the Ulivo's winning image will be put to the test in 2005, and then again in 2006. And the "specialization" of the center-right (and most of all of Berlusconi and Forza Italia) in winning nationallevel elections suggests caution for anyone who might be tempted to find pointers to the next national result in the local election results of these last few years. The elections for the 15 ordinary-statute regions, and the general election thereafter, will in fact have a substantially different character from those held in the last few years. The 2005 regional elections will provide a first test of whether the center-left has won the elections of the past three years (and with an increasing margin) simply because they were local elections or because a substantial number of Italians who voted center-right in 2001 no longer intend to do so. The substance of the election campaign will certainly be more national in character, as was the case in 2000, because of Berlusconi's invitation to voters to make a clear "choice of sides." Since then, the House of Freedoms, which has sought to "nationalize" local elections, has suffered repeated defeats as a result. But in an election that is effectively national in character, campaigns of this sort might begin to bear fruit. In the regional and general elections, the center-right could benefit by choosing to focus its campaign on the government and on Berlusconi's national leadership. Until then, it could be speculated that the alarming failure of Forza Italia in the European elections (more than in the local ones) could certainly be the result of an actual fall in Berlusconi's popularity and/or of dissatisfaction with the actions of the government over which he presides. But it could also 
be the result of mere circumstantial factors. In a vote of this sort, it could prove more difficult for the center-left to focus on local issues. There will be different forces at work, candidates of a different sort, a different election campaign (which is sure to have the mass media as its principal means of communication), and a different attitude on the part of the voters, geared toward electing a national leadership and government rather than a mayor and local council.

There are many factors that are likely to prove decisive in the next general election, but that are, at the moment, uncertain: ${ }^{26}$ the possibility of electoral reform and/or early elections, changes to the alternatives on offer, the climate of opinion, verdicts on the government's performance, the election campaign, the possibility that council elections in the large cities might be held at the same time, and the motivations underlying voters' choices. It is possible (however improbable it seems in the light of previous attempts) that electoral reform, introduced some time between now and 2006, will modify, perhaps radically, the constraints and opportunities confronting coalitions, parties, and voters. Furthermore, an early general election, which could even occur at the same time as the regional elections, cannot be ruled out. Without doubt, there will be changes in what is offered by coalitions, parties, candidates, and programs. The climate of opinion will also be important, as will the perceptions of "victory" and "defeat" associated with the main contenders. In all of this, it is likely that the verdict on the government's performance will play a role, and it is possible that Berlusconi will have an easy ride electorally if he can demonstrate to those who voted for him in 2001 that he has succeeded in carrying out at least some of the tasks he set for himself. This in turn points to the significance of the choices made by the main political actors in the run-up to the election campaign (which, one could argue, has already started) and during the election campaign proper, bearing in mind also that both could be affected by possibly radical changes to the present par condicio laws. The election, which will take place at the same time as council elections in some of the major cities, will provide an incentive for the political protagonists to try to exploit the arena that is most favorable to them in order to attract votes in the other arena as well, in particular, seeking the greatest return in areas (usually in the south) where small shifts in voting can result in significant differences in terms of seats. Finally, there is a real measure of uncertainty about how the voters will behave, given that in general elections they are not usually inclined (especially with regard to their choices of coalition) to change horses.

As we can see, the outcome of the 2005 election, and even more that of 2006, is far from being predictable. It is not easy to see how the 
winner of the 2004 local elections and those of the preceding years, the center-left, will manage the difficult task of presenting a program at a national level that offers leadership, clarity of aims, and unity among its political forces. Nor can it be predicted whether and how the losers of these last few years, the center-right, will succeed-even though it will be on communicative terrain in all probability more favorable to it-in defending government policies concerning which even those favorably disposed toward the center-right currently appear to harbor doubts.

- Translated by Doug Thompson and Gillian Ania

\section{Notes}

1. G. Legnante, "The 2003 Local Elections: First Local and Then National Defeats for the Casa delle Libertà," in Italian Politics: Italy between Europeanization and Domestic Politics, ed. S. Fabbrini and V. Della Sala (New York and Oxford: Berghahn Books, 2004), 63-79.

2. In Milan in 1997, the outgoing mayor, Marco Formentini, was supported only by the Northern League and was opposed to both the Ulivo candidate and that of the House of Freedoms, Gabriele Albertini.

3. In councils having more than 15,000 inhabitants (in the special-statute regions there are different demographic thresholds), mayors are elected directly in a two-part contest. The councils themselves are elected by the list system of proportional representation, the voter being able to cast a preference vote to choose among candidates on his or her chosen list. The lists associated with the winning candidate receive 60 percent of the seats.

4. In this chapter, the municipalities of Cesena and Urbino have not been considered as provincial capitals. The results of the elections held in these two municipalities are, however, shown in table B3 in the appendix.

5. G. Legnante, "Dal 2004 alle elezioni politiche, tra voto locale e voto nazionale," Italianieuropei 1 (2004): 83-92; G. Legnante, "Il voto locale e la politica nazionale," il Mulino 5 (2004): 857-867.

6. G. Legnante and P. Corbetta, "Cambiamento politico e stabilità elettorale," il Mulino 3 (2000): 513-526.

7. G. Baldini and G. Legnante, Città al voto. I sindaci e le elezioni comunali (1993-1998) (Bologna: il Mulino, 2000); G. Baldini, "Eleggere i sindaci, dieci anni dopo," il Mulino 4 (2002): 658-667.

8. The classification of the geo-political zones referred to (where the labels "industrial triangle" and "white belt" are replaced by "northwest" and "northeast," respectively) is that habitually used by the Istituto Cattaneo: "northwest” (Valle d'Aosta, Piedmont, Lombardy, Liguria), "northeast” (Veneto, Friuli-Venezia Giulia, Trentino-Alto Adige), "red belt” (Emilia-Romagna, 
Tuscany, Marche, Umbria), “center” (Lazio, Abruzzo, Molise, Sardinia), and "south" (Campania, Apulia, Basilicata, Calabria, Sicily).

9. On the European elections, see the chapter by Mark Donovan in this volume;

P. Natale and P. Segatti, “Europee 2004: un punto di svolta?" Italianieuropei 3 (2004): 21-32; P. Feltrin, "Europee 2004: sempre meno europee, sempre più nazionali?" Italianieuropei 3 (2004): 33-43; G. Pasquino, "Ciò che sappiamo dell'Ulivo," il Mulino 4 (2004): 629-638.

10. A. Di Virgilio, "Elezioni locali e destrutturazione partitica: la nuova legge alla prova," Rivista Italiana di Scienza Politica 1 (1994): 107-165; Baldini and Legnante, Città al voto.

11. Eight councils have been omitted from this table since they are difficult to classify in terms of national politics: two in which the outgoing center-left administration was defeated by a "civic" coalition, five in which an outgoing center-right administration suffered a similar defeat, and one in which the center-left defeated an outgoing "civic" administration.

12. Baldini and Legnante, Città al voto.

13. Legnante, "The 2003 Local Elections."

14. G. Baldini, P. Corbetta, and S. Vassallo, La sconfitta inattesa. Come e perché la sinistra ha perso a Bologna (Bologna: il Mulino, 2000).

15. R. Mannheimer, "Cofferati in vantaggio a Bologna. A Milano più consensi per la Colli," Corriere della Sera, 22 May 2004, 13.

16. A dynamic discussed in L. Verzichelli and F. Zucchini, "The New Parliament and the Start of a Decisive Legislature," in The Italian General Election of 2001: Berlusconi's Victory, ed. J. Newell (Manchester: Manchester University Press, 2002), 217-237.

17. P. Bellucci and P. Segatti, "Le risorse di un leader della sinistra: il caso Cofferati," il Mulino 5 (2002): 911-915.

18. Baldini, Corbetta, and Vassallo, La sconfitta inattesa.

19. F. Alberti, "La carta di Guazzaloca: votate Ulivo e anche me," Corriere della Sera, 5 June 2004, 17.

20. On this point, see also P. Corbetta and D. Tuorto, "La personalizzazione del voto per il sindaco," www.istcattaneo.org, link pubblicazioni/analisi.

21. P. Segatti, "La complessa stabilità di Trieste," il Mulino 3 (1997): 483-492; P. Segatti, "Il 'metodo Illy': le ragioni del voto in Friuli-Venezia Giulia," Italianieuropei 3 (2003): 37-48.

22. The data for the period 1997-2002 are taken from G. Baldini and G. Legnante, "Municipal Elections: Real Change or Simply Alternation?" in Italian Politics: The Second Berlusconi Government, ed. J. Blondel and P. Segatti (New York and Oxford: Berghahn Books, 2003), 59-77; the data for 2003 are taken from Legnante, "The 2003 Local Elections."

23. Segatti, "Il 'metodo Illy."

24. Baldini and Legnante, "Municipal Elections"; Legnante, "The 2003 Local Elections."

25. P. Natale, "Berlusconi e il consenso infedele," Italianieuropei 4 (2003): 33-46.

26. Legnante, "Il voto locale." 